\title{
Masonería y revolución liberal en España: la Confederación de Comuneros
}

\section{Freemasonry and liberal revolution in Spain: The Confederation of Comuneros}

Francisco Javier Díez Morrás

Universidad de La Rioja, España

jdiezmorras@hotmail.com

Recepción: 15 de junio 2019/Aceptación: 2 de septiembre de 2019

doi: https://doi.org/10.15517/rehmlac.v11i2.38480

\section{Palabras clave}

Confederación de Comuneros; Trienio Liberal; constitucionalismo; exaltación.

\section{Key words}

Confederation of Comuneros, Liberal Triennium, constitutionalism, exaltation.

\section{Resumen}

La Confederación de Comuneros nació en España a principios de 1821 dentro de la masonería, creada por miembros exaltados ante la moderación de esta. Pronto tuvo un gran número de integrantes, por toda España y singularmente por los ámbitos rurales. Se dotó de una estructura más sencilla que la masonería, adoptando una terminología emparentada con las revueltas comuneras del primer cuarto del siglo XVI. Entre sus fines estaba llevar a término una revolución liberal. Tras una primera crisis en octubre de 1822 y una escisión en febrero de 1823, pasó a la irrelevancia una vez derribado el sistema constitucional español.

\section{Abstract}

The Confederation of Comuneros began at the beginning of 1821 in the Masonic lodges and was created by exalted members as a reaction to the moderation of their brethren. Soon it had many members, spreading throughout Spain and uniquely in rural areas. It was equipped with a simpler structure than Freemasonry, adopting a terminology related to the communal revolts of the first quarter of the 16th century. Among its aims was to carry out a liberal revolution. After a first crisis in October 1822 and a split in February 1823, it

weakened, becoming irrelevant once Spain's constitutional system was demolished. 


\section{Introducción}

Al comenzar el Trienio Liberal la masonería era la única sociedad secreta implantada en toda España. La historiografía antiliberal, y algunos de los que habían preparado el levantamiento de 1820 pero que renegaron finalmente de aquellos hechos, le atribuyeron un protagonismo especial de carácter conspiratorio en el retorno al constitucionalismo. El marqués de Miraflores señaló por ejemplo que la masonería minaba al gobierno y que, a pesar de ser sofocada la revolución de julio de 1819, esta tenía sólidos fundamentos y "estendidas por la Masoneria sus ramificaciones por toda la Península, solo esperaba en todas partes un pronunciamiento positivo por una fuerza militar"'. Por su parte Alcalá Galiano, que participó activamente en los preparativos del levantamiento del 1 de enero de 1820 , justificaba años después su presencia debido a su fogosidad y bisoñez: "Era entonces, como confieso, ardiente mi fanatismo; mi edad, aunque ya no la de la verdadera juventud, una en que todavía ejercen grandísimo poder en el hombre las pasiones; mi natural más que lo comun apasionado..., todo contribuia á exaltarme”. Cargó en la masonería la responsabilidad de los hechos e incidió en su total influencia al decir sin ambages que fue la "sociedad restablecedora de la constitucion”. Ayudó a que se asentase esa percepción conspiradora de la masonería el haberse integrado en ella algunos de los líderes del levantamiento, particularmente Evaristo Fernández de San Miguel y el mismo Rafael del Riego4. Sin duda los debates promovidos en sus reuniones secretas habían coadyuvado a la difusión del liberalismo y a su restablecimiento, pero según Gil Novales eso no es suficiente para otorgarle tanta influencia’.

Parte del argumentario antimasónico y del análisis denigratorio posterior tiene que ver con el protagonismo que finalmente adquirieron algunos miembros de la masonería en el Trienio, período en el que no se prohibió, en el que nació la comunería, y en el que se vivió la llegada de sociedades extranjeras exaltadas como la carbonería. Las sociedades secretas experimentaron entonces un gran empuje. Como señaló Iris M. Zavala, prohibidas las sociedades patrióticas a finales de 1820 , los constitucionales desarrollaron aún más las secretas, organizadas para conservar y aumentar las libertades civiles. Por otro lado, reprimido o minorado el inicial espíritu revolucionario, el liberal más exaltado recurrió a la sociedad secreta, y vista la moderación que se fue apoderando de la masonería, se creó la de los comuneros para defender sus posturas y crear una red favorable a la revolución ${ }^{6}$. Surgió de miembros exaltados de una masonería instalada en la tibieza y a la que se habían sumado antiguos afrancesados?

El nacimiento de la Confederación de Comuneros se debió esencialmente a dos circunstancias, la proliferación de movimientos conspiratorios anticonstitucionales de

\footnotetext{
$1 \quad$ Marqués de Miraflores, Apuntes histórico-críticos para escribir la historia de la revolucion de España, desde el año 1820 hasta 1823 (Londres: Oficina de Ricardo Taylor, 1834), 28-29. 
los realistas, y en segundo lugar a la paralización un año después del pronunciamiento de Riego del proceso revolucionario pretendido por el liberalismo más exaltado ${ }^{8}$. Su éxito fue inmediato debido a la laxitud de sus líderes locales y a la integración en ella de un amplio espectro social ${ }^{9}$. Varias circunstancias ayudaron a su notoriedad. En primer lugar que, desde el punto de vista organizativo, se encontraba muy bien estructurada, pues la comunería bebió de la experiencia de la masonería, adoptando y adaptando los rituales introductorios y el desarrollo de las sesiones, aunque más simplificados. Por otro lado, fue importante la asunción de una mitología y unos símbolos propios enraizados en la tradición medieval e histórica española. El ejemplo está en su misma denominación y en los nombres tomados para su estructura, la cual partía de reuniones básicas llamadas 'torres', continuando por arriba con las 'merindades'. Los lugares de reunión eran los 'castillos de la libertad', donde había una ‘plazas de armas'. Sus líderes eran los ‘castellanos', y otros cargos estaban ocupados por los 'alcaides', los 'procuradores', etc. En tercer lugar, aunque se reglamentaron unos requisitos de acceso rigurosos, finalmente no lo fueron tanto; además las contribuciones económicas no resultaron exorbitadas, ni se exigieron de forma severa. A todo ello se sumó la sencillez de sus postulados, pues se ceñían a defender la Constitución, sin que ello trajese aparejada una actividad concreta más allá de la asistencia a las sesiones, la participación en los comentarios, debates y votaciones de las reuniones, y la promoción de alguna denuncia. Los comuneros más exaltados no lo eran por ser comuneros, sino porque venían creyendo en la revolución liberal, lo que les hizo sumarse a la comunería. Todo ello dio lugar a una gran heterogeneidad en el grado de compromiso de sus miembros, y en modo alguno se puede afirmar que la exaltación fuese una de sus características, a pesar de haber sido creada y liderada por los miembros más extremos del liberalismo español. No cabe duda de que precisamente el abandono del extremismo ayudó a que se extendiese en los ámbitos rurales, poco dados a radicalismos, con numerosos integrantes procedentes de capas sociales inferiores, y solo compuestos por exaltados en sus niveles superiores. Ejemplo del aumento de los elementos moderados dentro de la comunería fue la escisión que sufrió a nivel nacional en febrero de 1823.

\section{La comunería, una sociedad secreta española}

No son muy numerosos los trabajos sobre la Confederación de Comuneros, aunque en las últimas cuatro décadas se han elaborado investigaciones muy relevantes y se ha avanzado de manera notable en su estudio ${ }^{10}$. Durante mucho tiempo las referencias a ella

$8 \quad$ Acerca de la actividad liberal exaltada en el Trienio, su impulso y motivaciones, Sophie Bustos, "La nación no es patrimonio de nadie. El liberalismo exaltado en el Madrid del Trienio Liberal (1820-1823): Cortes, gobierno y opinión pública”, (Tesis de Doctorado en Historia, Universidad Autónoma de Madrid, 2017).

9 Basándose en el periódico El Zurriago, Iris Zavala señala que en poco tiempo se llegó a los 6o.ooo comuneros en toda España, Zavala, Masones, 74.

10 Aparte del veterano trabajo de Zabala, arriba citado, se deben añadir, Alberto Gil Novales, Las Sociedades patrióticas (1820-1823). Las libertades de expresión y de reunión en el origen de los partidos políticos (Madrid: Tecnos, 1975), 604 y ss.; Marta Ruiz Jiménez, El liberalismo exaltado. La confederación de comuneros españoles durante el Trienio Liberal (Madrid: Ed. Fundamentos, 2007) y Michel Mondejar, "Alliances et conflits au sein des sociétés secrètes libérales: la confédération des chevaliers comuneros ou les limites de l'illusion démocratique durant le triennat constitutionnel 1820-1823" (Tesis de Doctorado en Historia, Universidad de Aix-Marseille I, 2007). Por otro lado, tanto Sánchez Martín, "Rafael del Riego", como Bustos, "La nación no es patrimonio de nadie", han abordado el estudio de los liberales más exaltados y su vinculación con la comunería. Otros han incidido en ámbitos locales o regionales como: Antonio Ortiz García, "Masones y comuneros en la Diócesis de Sigüenza tras el Trienio liberal (1823)”, Wad-al-Hayara, Revista de estudios de Guadalajara 13 (1986): 263-275; Ramón López 
se basaron en la obra del marqués de Miraflores, contrario y crítico con todo lo relacionado con las sociedades secretas ${ }^{11}$; en la de Vicente de la Fuente, la cual ofreció una visión no menos negativa y sediciosa de la comunería ${ }^{12}$; o en Alcalá Galiano, crítico contumaz de las sociedades secretas en general y de la comunería en particular, de la que dijo que si no hubiera sobrevenido la catástrofe que se llevó por delante el liberalismo, hubiera oscurecido o hasta destruido a su sociedad madre, es decir, a la masonería ${ }^{13}$.

Fue precisamente Alcalá Galiano quien atribuyó al literato Bartolomé José Gallardo la denominación comunera de la nueva sociedad secreta nacida en 1821. Según él, era "escritor afectadísimo, político violento más que atinado ó agudo, se distinguia por su aficion ardorosa á las cosas de su patria y lengua" ${ }^{14}$. Sin embargo, Gil Novales no le dio excesivo crédito a esta atribución ${ }^{15}$. Lo que sí es evidente es que fue la revuelta de 1521 y su recuperación como jalón histórico la que inspiró su nombre. El proyecto político liberal nacido en Cádiz en 1810 que dio lugar al nacimiento del Estado-Nación español necesitó también un sustento histórico capaz de argumentar y afianzar en el pasado las novedades liberales. Un ejemplo de ello, quizás uno de los más importantes, fue la reinterpretación del episodio comunero ${ }^{16}$.

Entre 1520 y 1522 se produjeron en Castilla varios levantamientos armados, normalmente urbanos, desencadenados por distintas causas que van desde los profundos cambios políticos debidos a la llegada de los Austrias, hasta la necesidad de afrontar reformas fiscales y comerciales. Durante más de dos siglos, coincidiendo con la monarquía de los Austrias, la guerra de las Comunidades de Castilla fue interpretada como un levantamiento ilegítimo contra el rey. No es este el momento de adentrarse en aquellos movimientos y sus motivaciones, existiendo interesantes trabajos que lo abordan ${ }^{17}$. Sin embargo, en el Trienio Liberal, coincidiendo con el tercer centenario de la ejecución de los líderes Juan de Padilla, Juan Bravo y Francisco Maldonado, ocurrida la mañana del 24 de abril de 1521, se llevó a cabo una recuperación definitiva de la guerra de las Comunidades, que en realidad venía haciéndose desde unos años antes, transmutándose en una suerte de preludio de las libertades españolas. Con ello se convirtió en un hito anacrónico de la mitología liberal. Tal fue su éxito que aquellos miembros de la masonería que a partir de 1821 se mostraron disconformes con la tibieza de esta sociedad secreta, conformaron una nueva

Caneda, "La sociedad secreta de Caballeros Comuneros de Astorga", Astórica 4 (1986): 55-104; y "Astorga 1824. Depuración política y ficha policial sobre caballeros comuneros, liberales exaltados, masones y demás afectos a la ideología liberal”, Astórica 8 (1989): 185-198; Ramón Arnabat, La revolució de 1820 i el Trienni Liberal a Catalunya (Vic: Eumo editorial, 2001).

11 Marqués de Miraflores, Apuntes histórico-críticos, 78-81. Este autor dijo de los comuneros que "deseando combatir á sus antiguos hermanos, fomentaba el desorden, y con él la popularidad de su Corporacion, admitiendo en ella hasta la hez de la sociedad".

12 Vicente de la Fuente, Historia de las sociedades secretas antiguas y modernas en España, especialmente de la Francmasonería (Lugo: Imprenta de Soto Freire, 1870 y 1881).

13 Alcalá Galiano, Recuerdos de un anciano, 377-420.

14 Alcalá Galiano, Recuerdos de un anciano, 377.

15 Alberto Gil Novales, "Gallardo y Blanco, Bartolomé José", en Diccionario biográfico de España (1808-o833). De los orígenes del liberalismo a la reacción absolutista (Madrid: Fundación Mapfre, 2010).

16 Enrique Berzal de la Rosa, "El mito de los comuneros de Castilla en la construcción del Estado-Nación español", Alcores 12 (2011): 55-73.

17 Se pueden destacar varios trabajos dispares pero igualmente interesantes: José Antonio Maravall, Las comunidades de castilla. Una primera revolución moderna (Madrid: Revista de Occidente, 1963); Joseph Pérez, Los comuneros (Madrid: Historia 16, 1997); Enrique Berzal de la Rosa, Los comuneros. De la realidad al mito (Madrid: Sílex, 2008). 
que se autodenominó Confederación de Comuneros Españoles ${ }^{18}$. La lucha de los comuneros castellanos se convertía definitivamente en el símbolo de la lucha contra la tiranía ${ }^{19}$.

La rehabilitación de los comuneros castellanos se venía fraguando desde hacía más de dos décadas y tuvo un hito literario fundamental, la oda "A Juan de Padilla" escrita por Manuel José Quintana en $1797^{20}$. Quintana fue un gran lector de obra histórica y conocedor de la Historia del reinado del Emperador Carlos V, de William Robertson ${ }^{21}$, y de la Historia de la vida y hechos del emperador Carlos $V$, de Sandoval ${ }^{22}$, las cuales rememoraron aquella lucha castellana. En la larga oda se muestra a Padilla como un héroe frente al despotismo y la opresión de un monarca venido de fuera. Pero Quintana incide en que el levantamiento comunero había sido una lucha entre hermanos y le atribuye a su líder palabras de verdadero "revolucionario moderno", como señala Torrecilla, autor que ha incluido el mito comunero dentro de los mitos del progresismo español de principios del siglo XIX. Pero como sigue diciendo este mismo autor, para hacer la propuesta más aceptable a los españoles, a través de Padilla se hizo ver que la libertad estaba "hondamente enraizada en la tradición nacional”, por lo que luchar por ella no era sino rescatar prácticas de gobierno injustamente erradicadas ${ }^{23}$. Tras la llegada de los franceses en 1808 , la figura de Padilla se asoció únicamente a la defensa de las libertades, y otros como Canga Argüelles defenderían en 1811 que la rebelión del “inmortal Padilla” contra Carlos I fue el preludio del levantamiento español contra el francés ${ }^{24}$.

La animadversión hacia el primer Austria en los inicios del siglo XIX fue habitual. Martínez Marina lo criticó por extranjero en 1813; Capmany, en 1809, se acordó de los comuneros y en la misma línea rechazó la llegada de un monarca que no era español; por su parte, Jovellanos señaló que en la revuelta comunera los intereses de la nación fueron vencidos por la intriga y la fuerza; finalmente, Blanco White se posicionaría en contra de la llegada de un rey que ocasionó muchos perjuicios ${ }^{25}$. El 21 de noviembre de 1811 se publicó en el Semanario patriótico un texto a modo de carta escrita por Padilla a las Cortes en el que se criticaban los tiempos del antiguo régimen y evidentemente a Carlos I, pidiendo a los "restauradores de la libertad española" que no se olvidasen de él ${ }^{26}$. Por su parte, uno de los primeros liberales, Francisco Martínez de la Rosa, publicaría en 1814 La viuda de Padilla, obra de gran éxito escrita dos años antes ${ }^{27}$.

18 Así se denomina en sus estatutos. En concreto, la edición que utilizamos en esta investigación es: Estatutos de la Confederación de Comuneros Españoles. Precede un resúmen de la historia de las Comunidades de Castilla (Valencia: Imprenta de José Ferrer de Orga, 1822). En esta obra se incluye también el Código Penal de la Confederación de Comuneros Españoles, y el Reglamento para el gobierno interior de la Confederación de Comuneros Españoles. Al primer documento denominaremos a partir de ahora Estatutos, al segundo Código Penal y al tercero Reglamento y así serán citados a partir de ahora.

19 José Álvarez Junco, Mater dolorosa. La idea de España en el siglo XIX (Madrid: Taurus, 2001), 223.

20 Manuel José Quintana, Poesías patrióticas (Madrid: Imprenta Real, 1808).

21 William Robertson, The History of the Reign of the Emperor Charles V (Dublin: Smith, 1769).

22 Prudencio de Sandoval, Historia de la vida y hechos del emperador Carlos V (Zaragoza: 1634).

23 Jesús Torrecilla, España al revés. Los mitos del pensamiento progresista (1790-1840) (Madrid: Marcial Pons, 2016), 121-124.

24 José Canga Argüelles, Reflexiones sociales, ó idea para la Constitución española, que un patriota ofrece a los representantes de Cortes (Valencia: Imprenta de José Estevan, 1811), 6.

25 Torrecilla, España al revés, 127.

26 Semanario patriótico, "Juan de Padilla, general del pueblo castellano, al congreso nacional", 21 de noviembre de $1811,409$.

27 Francisco Martínez de la Rosa, La viuda de Padilla (Madrid: Imprenta que fue de García, 1814). 
El mito comunero se asoció a finales del siglo XVIII con las ideas revolucionarias francesas, pero tras la entrada de los franceses experimentó una primera transformación al hacerse hincapié en la condición extranjera de Carlos I, sin duda puesta fácilmente en relación con la llegada del francés José I y la opresión napoleónica. Con ello se acentuó una fuerte connotación patriótica. Los comuneros y sus héroes se inscribirán entonces en la larga lista de mitos hispanos. Finalmente, avanzado el Trienio Liberal, se observa una identificación de las supuestas y antiguas libertades españolas que defendieron los héroes de Villalar, con el liberalismo más exaltado. Sin duda, ayudó a que el liberalismo tomase definitivamente como propia la guerra de las Comunidades el hecho de que Riego hiciese un uso político del mito. Lo hizo junto con Arco-Agüero el 13 de julio de 1820, a escasos días de haberse abierto las sesiones de las Cortes, en un escrito dirigido a ellas en nombre del Ejército de Andalucía. En él habla de los hijos de Villalar al rememorar los hechos que a principios de año había traído el constitucionalismo. Dice en concreto: "Los soldados españoles, mirados y despreciados hasta entonces como maquinas venales manifestaron que eran hijos de los que en Villalar no pudieron resistir las falanges instruidas que la tiranía dirigió contra ellos, y patriotas como sus padres acudieron pronto á donde resonaba el glorioso éco de Patria y libertad”28. También el propio Riego sería asociado a Padilla en loas escritas y publicadas en los primeros meses de 1820, como ha estudiado Sánchez Martín, calificándole por ejemplo de "émulo de la gloria de Padilla" ${ }^{29}$. Pero es que la celebración del tercer centenario de la ejecución de los líderes comuneros fue general y consensuada entre todos los liberales, tal y como se puede ver en las numerosas intervenciones de los diputados en las Cortes y en los homenajes que se aprobaron ${ }^{30}$.

Un hecho fundamental para la recuperación de los Comuneros castellanos del siglo XVI y su incorporación al imaginario liberal estuvo en el homenaje que promovió Juan Martín ‘el Empecinado', uno de los héroes de la Guerra de la Independencia y ahora ardiente liberal, hecho que tuvo una gran repercusión. En la sesión de las Cortes de 13 de abril de 1821 se dio noticia de un oficio de 11 de abril del secretario del despacho de la Gobernación en el que informaba que el jefe político de Salamanca le había comunicado el día 7 que se había difundido la voz de que en los próximos días 23 y 24 de abril se iba a celebrar un homenaje con motivo del tricentenario de la ejecución de Padilla, Bravo y Maldonado ${ }^{31}$. Como se ha señalado, todo había sido iniciado por 'el Empecinado'. El 4 de abril, siendo general en la plaza de Zamora, ordenó que, con motivo del tercer centenario de la ejecución de los héroes de Villalar, se exhumasen sus restos y se depositasen provisionalmente en una urna que sería custodiada en la parroquia del pueblo. El jefe político redactó al efecto un oficio ${ }^{32}$. Los supuestos restos de Padilla, Bravo y Maldonado fueron exhumados el 13 de abril, dejándose en manos de las Cortes la decisión sobre los mismos ${ }^{33}$.

28 El Constitucional, 30 de agosto de 1820, 4. Todo el texto se reproduce en los números 478 a 481 del mismo periódico. 29 Sánchez Martín, Rafael del Riego, 406 y 413.

3o Josep Ramón Segarra, "La turbación de los tiempos: ruptura temporal e historia en la construcción de las culturas políticas”, en La creación de las culturas políticas modernas. 1808-1833, coord. por Miguel Ángel Cabrera y Juan Pro (Madrid: Marcial Pons, Prensas de la Universidad de Zaragoza, 2014), 171.

31 Diario de Sesiones de Cortes (DSC), sesión de 13 de abril de 1821, 1.027-1.028.

32 Extracto del expediente militar instructivo formado para la exhumacion de los huesos de los héroes castellanos Padilla, Bravo y Maldonado, y copias de la órden, acta celebrada y decreto de aprobación (Madrid: Imprenta de D. Mateo Repullés, 1821), 3-4. 
Estas se sumaron al homenaje y el 18 de abril se propuso la colocación de los nombres de los héroes de Villalar en el salón de sesiones de las Cortes, además de la del aragonés Lanuza. Como dijo el diputado Francisco Díaz Morales, "poco hay que decir para apoyar esta indicación” ${ }^{34}$. Finalmente en la sesión extraordinaria del 24 de junio de 1821 la recién creada comisión especial encargada de informar acerca de todas las propuestas de distintos diputados, hizo una larga recapitulación de los hechos que llevaron a la muerte de los héroes comuneros en 1521, insistiendo en la pérdida de las libertades tanto de Castilla como de Aragón, y propuso un decreto para declarar beneméritos de la patria en grado heroico a Padilla, Bravo y Maldonado, y a los aragoneses Lanuza, Heredia y Luna, así como la erección de sendos monumentos conmemorativos en Villalar y Zaragoza ${ }^{35}$.

Sin embargo, los comuneros castellanos del siglo XVI, patrimonio inicial de todos los liberales del Trienio, pasaron definitivamente al acervo de solo una parte de ellos, el de los exaltados. Las distintas visiones del liberalismo doceañista que fueron madurando entre 1812 y 1820 dieron lugar a variadas interpretaciones del texto constitucional, naciendo a consecuencia de ello dos grandes familias entre los liberales: los moderados y los exaltados. Los liberales empeñados en llevar hasta sus últimas consecuencias el texto constitucional, fueron los que fundaron ese año 1821 una sociedad secreta de antiguos masones que, precisamente, tomó como nombre el de los comuneros ${ }^{36}$.

\section{Una escisión de la masonería}

La Confederación de los Caballeros Comuneros Españoles, que así es como se autodenominó esta nueva sociedad en sus estatutos fundacionales ${ }^{37}$, nació en enero de 1821 de la mano de 28 masones desertores ${ }^{38}$. Miñano explicó su nacimiento y evolución de forma muy sintética:

Algunos masones de los mas exaltados se separaron de la sociedad á principios de 1821, y crearon la Comuneria que parece que al pronto se propuso hacer la guerra á los masones. Entraron comuneros muchos hombres de buena fé, que cansados de ver la preponderancia de los masones, y recelando que trastornasen el estado, abrazaron aquel partido, creyendo que no habia otro medio mas eficaz de sostener la constitucion. Pero la division entre las dos sociedades duró poco, porque los masones mas astutos que los comuneros, y perfectamente enterados de los secretos de estos, los atrajeron á sus intereses, y el odio al ministerio fue el punto de reunion de unos y otros ${ }^{39}$.

34 DSC, sesión de 18 de abril de 1821, 1.119.

35 DSC, sesión extraordinaria de 24 de junio de 1821, 2.456-2.462.

36 Como señaló Berzal de la Rosa, "la entronización de Padilla, Bravo y Maldonado como mártires excelsos de la libertad y la patria españolas alcanza su cénit en el Trienio Liberal (...) sobre todo, en el discurso del liberalismo exaltado", Berzal de la Rosa, "El mito de los comuneros de Castilla", 58-59.

37 Estatutos. Por otro lado se publicó en 1822 la obra Constitución de la confederacion de los caballeros comuneros, y reglamento para el gobierno interior de las fortalezas, torres y castillos de todas las merindades de España. Con algunas notas, que aunque no se pusieran, no por eso dejaria de irlas haciendo á sus solas el lector (Madrid: Imprenta del Imparcial, 1822). Esta, como su título indica, reproduce, con ciertas variaciones, el texto del reglamento comunero, añadiendo una serie de comentarios y precedida de un "Prólogo, ó como se llame". Tanto el prólogo como las notas están escritas por alguien aparentemente liberal pero extremadamente crítico con la comunería, a la que sin duda pretende denigrar y sacar a la luz sus contradicciones y defectos.

38 Gil Novales, El Trienio liberal, 26.

39 Sebastián Miñano, Examen crítico de las revoluciones de España. De 1820 a 1823 y 1836 (París: Imprenta de Crapelet, 1837), $74-75$. 
El 21 de febrero ${ }^{40}$, reunidos en Madrid en el 'alcázar de la libertad', nombre que se otorgó al lugar de reunión de la asamblea general, estuviese donde estuviese, la comunería aprobó los documentos que iban a servir para regir su organización. Se trata de tres textos prolijos elaborados sin duda por juristas y personas totalmente comprometidas con el liberalismo, lo que acerca su autoría a Juan Romero Alpuente. En concreto aprobaron unos estatutos generales, un reglamento para el gobierno interior de las fortalezas y en tercer lugar lo que denominaron un código penal, que no era sino un reglamento disciplinario de carácter interno que reproducía el esquema judicial del Estado. Entre sus fundadores se encontraban Francisco López Ballesteros, Francisco Serrano, José María Torrijos, José Manuel del Regato, que después se revelaría como agente absolutista ${ }^{41}$, y Juan Romero Alpuente $^{42}$. Este último fue sin duda su líder, y entonces era magistrado y diputado ${ }^{43}$.

Tal y como señaló Gil Novales, fue a partir del Trienio cuando Romero Alpuente alcanzó relevancia nacional tras ser elegido diputado en 1820 y 1821, erigiéndose en un activo paladín de la minoría exaltada ${ }^{44}$. A la intensa actividad política que desarrolló en las Cortes y en los círculos liberales se unió una prolífica obra, plasmando en numerosos escritos sus imperturbables ideales políticos y sociales, así como las circunstancias y avatares que vivió. Como protagonista principal que fue, escribió sobre el nacimiento de la comunería y su breve trayectoria, particularmente en su Historia de la revolución de España. En concreto dice en esta obra que la comunería nació "con sólo el objeto de defender a todo trance y por cuantos medios fuesen posible los derechos y libertades de la nación y de los españoles en particular según estaban declaradas en la constitución política de la monarquía reconociendo por base inalterable que la soberanía residía esencialmente en la nación española...” ${ }^{45}$. Es una declaración clara y precisa, repetida por los comuneros de manera habitual y que pone de manifiesto que muchos de aquellos que apoyaron en 1820 la reinstauración del régimen constitucional vieron que era necesaria una acción directa y continuada en su favor, y un nuevo colectivo que la liderase. Quiso destacar Romero Alpuente la ética especial que guiaba a los comuneros, a los cuales se les prohibía, por ejemplo, favorecer a sus miembros para empleos públicos, sin perjuicio de que la confederación estimase que "por el interés de la patria" se pudiese recomendar algún miembro al gobierno. El juramento que se prestaba incidía en lo mismo al exigir la defensa de la Constitución hasta tal punto de tener que manifestar su preferencia a morir con las armas en la mano que "sucumbir a la tiranía"

Romero Alpuente indicó que los fundadores de la comunería procedían de la masonería, siendo él mismo una muestra de ello. Sería una suerte de depuración, pues quedaron en

$40 \quad$ Constitución de la confederacion de los caballeros comuneros, 31 y 49.

41 Gil Novales, El Trienio liberal, 26.

42 Gil Novales, Las Sociedades Patrióticas, 604, citando a D. Elizalde, Los Sueños: (Madrid: 1822), 67; Ruiz Jiménez, El liberalismo exaltado, 21; Juan Romero Alpuente, Historia de la revolución española y otros escritos, ed. Alberto Gil Novales, vol. 2 (Madrid: Centro de Estudios Constitucionales, 1989), 314.

43 Alberto Gil Novales, "Estudio preliminar", en Juan Romero Alpuente, Historia de la revolución española y otros escritos (Madrid: Centro de Estudios Constitucionales, 1989). Con la reinstauración constitucional de 1820 fue nombrado jefe político interino de Murcia, puesto que abandonó tras ser elegido en mayo diputado por Aragón, donde permaneció hasta 1822. En las Cortes se erigió en líder de los exaltados. Además de fundar la comunería en 1821, formó parte de la Sociedad Landaburiana. Gil Novales lo califica como el diputado más jacobino del naciente liberalismo español.

44 Gil Novales, "Estudio preliminar", XL.

45 Gil Novales, "Estudio preliminar", XL.

46 Romero Alpuente, Historia de la revolución española, 314-315.

REHMLAC+, ISSN 1659-4223, vol. 12, no. 2, diciembre 2019 / junio 2020 
la masonería los "hombres ambiciosos cuyo único objeto le reducían a mejorar su suerte personal con los empleos del estado”. Quizás con cierta exageración decía que en un año los comuneros habían llegado a contar con merindades o juntas en todas las provincias, asegurando que se habían alcanzado los cien mil miembros. También apuntaba una de las características de la comunería, su notable presencia entre los militares. En una intervención en la Sociedad Landaburiana el 22 de diciembre de 1822 ponderó de manera elocuente a los comuneros diciendo que sus miembros "son los españoles escogidos... decididos a sostener la Constitución de modo que dentro de poco todos (hasta las mujeres) serán comuneros” ${ }^{7}$.

El objeto de la comunería fue expresado de forma muy sintética en el artículo 3 de sus estatutos y se acerca plenamente a lo señalado por Romero Alpuente, quizás su redactor. No era otro que "sostener á toda costa los derechos y libertades del pueblo Español, segun están consignadas en la Constitucion política de la monarquía; reconociendo por base inalterable su artículo tercero" ${ }^{48}$. Este artículo constitucional es el que hacía referencia a que la soberanía residía en la nación. No deja de ser significativa esta breve manifestación que, interpretada literalmente, y a excepción del ambiguo "a toda costa", carece de extremismos y podría ser asumida sin ambages por todos los liberales, incluidos aquellos enmarcados dentro del liberalismo moderado. La necesidad de tener que reafirmar en los estatutos esos principios tan básicos y generales del constitucionalismo es muestra de que no todo el liberalismo español luchaba de igual manera en 1821, apenas un año después del restablecimiento constitucional, por la consolidación del nuevo sistema político ${ }^{49}$.

Ya se ha adelantado que la fuente historiográfica más importante para desentrañar los inicios de la comunería ha sido durante mucho tiempo la obra de Vicente de la Fuente, Historia de las sociedades secretas antiguas y modernas en España ${ }^{50}$. En el capítulo IV, parágrafos XXXV al XXXVIII, aborda la trayectoria de la masonería, y en el XXXIX se centra en la comunería ${ }^{51}$. En realidad su texto no es una elaboración propia, y honradamente lo manifiesta al comienzo del mismo al señalar la conveniencia de dejar constancia de que fue publicado en la Biblioteca de la Religión, ó sea, Coleccion de obras contra la incredulidad $y$ errores de estos últimos tiempos, que comprende diversas obras de distintos autores distribuidas en 25 tomos publicados entre 1826 y $1829^{52}$. Y así es. El parágrafo VII del último tomo de esta obra tiene por título "De las Sociedades secretas en España” y es transcrito completamente por De la Fuente desde el comienzo de su capítulo, notas a pie de página incluidas ${ }^{53}$. Por tanto, la postura totalmente crítica de este autor, aunque corroborada por él, procede de la fuente anterior.

La inclusión del texto en la Biblioteca de la Religión es una muestra de la firme oposición y condena que la Iglesia católica venía manifestando con respecto a las sociedades

47 Romero Alpuente, Historia de la revolución española, 39.

48 Estatutos, 49.

49 Como indicó Marta Ruiz Jiménez, la razón de ser de la comunería y del liberalismo exaltado fue la defensa de todo aquello que el liberalismo moderado no quiso o no se atrevió a realizar, Ruiz Jiménez, El liberalismo exaltado, 12.

50 De la Fuente, Historia de las sociedades secretas.

51 De la Fuente, Historia de las sociedades secretas, 229-234.

52 Biblioteca de la Religion, ó sea, Coleccion de obras contra la incredulidad y errores de estos últimos tiempos, 25 vols. (Madrid: Imprenta de D. E. Aguado, 1826-29).

53 Biblioteca de la Religion, 58-78. 
secretas, en consonancia con la posición de la Corona, y tiene especial interés por haber sido incluido pocos años después de la desaparición de la comunería. Pero en realidad el texto de la Biblioteca de la Religión tampoco es una obra publicada en esa colección por primera vez, pues reproduce el texto titulado Noticia acerca de las Sociedades secretas organizadas en España hasta el año de 1823 y sobre las de Cataluña en particular, de fecha y autor desconocidos, posiblemente publicado poco después del final del Trienio Liberal ${ }^{54}$. Tal y como hemos podido comprobar, la Biblioteca de la Religión copió ese manuscrito anónimo casi literalmente, pues solo realizó leves modificaciones de ciertas expresiones y términos.

La Noticia es un texto propio de un momento postconstitucional escrito para zaherir y denigrar a las sociedades secretas en general al poco de ser prohibidas. La reproducción de su contenido durante décadas a través de las dos obras citadas — hay que recordar la tardía publicación de la obra de De la Fuente-, ayudó a considerar a la comunería durante todo el siglo XIX como una sociedad totalmente perniciosa para el afianzamiento del liberalismo, por supuesto el moderado.

La obra comienza señalando que "La España defendida por el Espiritu Religioso de sus pueblos, y escudada por el Tribunal investigador de la Inquisicion hubiera rechazado largo tiempo las ideas del Filosofismo, cuyas funestas consecuencias experimentó la Francia á fines del siglo ultimo". En definitiva, señalaba que en España no hubo masones antes de 1808 "porque si hubieran existido no se hubieran ocultado á la vigilancia del Sto. Oficio". Sin embargo, con la Guerra de la Independencia los franceses propagaron la masonería, aunque tras su salida perdió influencia política ${ }^{55}$. Pero según la misma obra, a partir de 1815 y 1816 tomaría otro cariz, pues los “descontentos”, los liberales y algunos afrancesados comenzaron a organizar logias, siendo los masones quienes lideraron la conspiración de 1820, siguiendo con ello una idea largamente defendida entonces por los antiliberales. Sería durante el Trienio Liberal, con un gobierno "enteramente entregado á los masones" que ocuparon todo el poder, cuando comenzaría una pugna entre estos debida a su ambición y a rivalidades personales, llevando todo ello a la división de los masones y a la creación de una "secta nueba". La Noticia sigue diciendo que esta secta adoptó el nombre de comuneros en memoria de "antiguos recuerdos de una lucha armada, que por la defensa de algunos derechos populares habia osado atacar el poder de Carlos $5^{\circ}$ ". El texto incide y reconoce el éxito inicial de la nueva sociedad secreta al indicar que acudieron los adeptos de todas partes fruto de las escasas exigencias ofrecidas para su integración en ella, y señala que sus fundadores fueron José María Moreno Guerra, Francisco Díaz Morales, José Manuel del Regato, Nicolás [Santiago y] Rotalde y Santiago Jonama y Bellsolá56.

En cuanto a su organización, indica que se distribuía en torres y en juntas provinciales presididas por el gran castellano. Destaca que tras ello convivieron las dos sociedades, masonería y comunería, en una constante pugna por alcanzar el poder "con iguales miras democraticas”, palabra esta con connotaciones totalmente revolucionarias, y rivalizando en

\footnotetext{
54 Archivo General de Palacio (AGP), Papeles reservados de Fernando VII, t. 67, doc. 9, fols. 214-221.

55 AGP, Papeles reservados de Fernando VII, t. 67, doc. 9, fols. 214 rto. y vto.

56 AGP, Papeles reservados de Fernando VII, t. 67, doc. 9, fols. 214 vto.-215 rto.
} 
la inmoralidad profunda. Aunque eran menos, los masones coparon los puestos políticos más importantes por ser más diestros y experimentados, siendo 52 diputados masones en las Cortes de 1822-1823, por 21 los comuneros. Dice que la pugna estalló finalmente el 19 de febrero de 1823 al ver los masones que los comuneros iban a ocupar la mayoría de los ministerios del gobierno. Los primeros reunieron al "populacho de Madrid" en el Palacio Real obligando a Fernando VII a mantener a los ministros que acababa de destituir en beneficio de otros comuneros. Este suceso fue utilizado por el autor de la obra para atacar a la Constitución, la cual no habría servido sino para acrecer la ambición y los caprichos de los nuevos políticos que gobernaban España. No obstante, ambos grupos eran capaces de unirse con un fin común, luchar contra los realistas ${ }^{57}$.

La comunería se extendió de manera rápida, existiendo el doble de torres comuneras que logias masónicas al admitirse en aquellas todo tipo de personas, desde moderados hasta los más radicales. Ambas sociedades ejercían su influencia en la política y tenían sus propios periódicos. En el caso comunero fueron principalmente El Eco de Padilla y El Zurriago. Además la asamblea comunera estaba en contacto con cada asamblea provincial, al mando de la cual estaba su castellano. Se señalaba no sin exageración que ambas sociedades gobernaban la península bajo el reinado de la Constitución, pero sin ocuparse del bien de la patria porque ambas se disputaban el poder en un "conflicto de ambiciones opuestas", aunque habitualmente salía victoriosa la masonería ${ }^{58}$.

Es interesante la reflexión que hace el autor de la Noticia acerca de la Sociedad del Anillo, pues si las dos anteriores le parecían aborrecibles, no lo era tanto esta, formada por "hombres moderados amigos de las livertades publicas", que formó un partido de oposición para mejorar la suerte del país y cuyo objeto era reformar la Constitución por ser "demasiado viciosa y demasiado democrática”, apuntando al plan de cámaras tendente a conformar una segunda cámara que equilibrase el poder de las Cortes. La ponderación del autor del texto hacia los anilleros es continua, lo que le aproxima sin duda a ellos, calificando a sus miembros de ilustrados, sabios, patrióticos, nutriéndose hasta de masones y de quien fuera ministro, Calatrava ${ }^{59}$. Fueron atacados y vencidos por masones y comuneros, especialmente tras lo del 7 de julio de 1822, al haberles atribuido movimientos conspiratorios anticonstitucionales, con lo que decidieron disolverse. Por tanto, para el autor de la Noticia las sociedades secretas no eran negativas por secretas, sino por conspiradora la masonería y exaltada la comunería. Pero todo fue a peor con la llegada desde Italia de los carbonarios, aunque serían derrotados y apartados por las dos sociedades españolas ${ }^{60}$.

Se habla también de otras sociedades secretas como los Europeos, venida del extranjero y asentada en Barcelona, que se nutrió de italianos antiguamente carbonarios. Contaban con un cuerpo de mercenarios del que se llegaron a servir tanto la masonería como la comunería para combatir a los carbonarios, misión "que la desempeñaron con toda la finura italiana”. En Madrid se conformó la Asociación Francesa bajo los auspicios

\footnotetext{
AGP, Papeles reservados de Fernando VII, t. 67, doc. 9, fols. 215 vto.-216 rto. AGP, Papeles reservados de Fernando VII, t. 67, doc. 9, fols. 216 vto.-217 rto. AGP, Papeles reservados de Fernando VII, t. 67, doc. 9, fols. 217 vto. AGP, Papeles reservados de Fernando VII, t. 67, doc. 9, fols. 218 rto.
} 
del Grande Oriente Español, es decir, de la masonería, teniendo elementos en Bilbao y en Barcelona ${ }^{61}$.

Gil Novales destacó el odio que se generó entre ambas sociedades secretas al haberse escorado la masonería hacia la derecha y haber tomado la comunería el sentido inverso, destacando esta última por su cerrada defensa del cumplimiento de la Constitución en línea con los liberales exaltados que la fundaron. A pesar de ello, no existían entre ambas sociedades claras diferencias sociales en sus líderes, sino que eran sobre todo disputas ideológicas y otras vinculadas a la obtención del poder político. No obstante, la comunería pretendió acercarse al pueblo, a las capas sociales que no formaban parte de la elite, de la que sí eran parte sus dirigentes ${ }^{62}$. Sin duda alguna, al ser los comuneros mucho más numerosos que los masones, era normal que su composición estuviese más cerca de la estructura social del país, donde, evidentemente, el grueso de su población pertenecía a los sectores más populares. El propio nombre de esta sociedad secreta, que evoca a las revueltas castellanas producidas 300 años antes, es además una muestra de esa vocación popular. Por otro lado, la ciudadanía debía tomar parte directa en las decisiones en cumplimiento de la Constitución, lo que en modo alguno significaba una cerrada defensa del jacobinismo o el republicanismo a pesar de ciertos guiños. En fin, como señaló Ruiz Jiménez, la comunería pudo nacer del aburguesamiento de la masonería ${ }^{63}$. La misma autora ha apuntado hacia los primeros movimientos que aceleraron su creación, pues si su fundación se produjo a comienzos de 1821, todo se pudo generar en torno al malestar creado en grupos de la masonería por el nombramiento del general José María de Carvajal y Urrutia como capitán general de Castilla la Nueva en noviembre de $1820^{64}$. A pesar de que la Iglesia consideraba entonces a la masonería como una institución satánica, en realidad en 1820 había dejado de ser una sociedad revolucionaria, por lo que algunos miembros que deseaban retomar la revolución y defender firmemente la Constitución se decidieron por la escisión ${ }^{65}$.

\section{Estructura y organización comunera}

La prolijidad de los tres documentos que regularon esta sociedad es muestra de una elaboración pensada y detenida carente de improvisación y con una clara inspiración masónica ${ }^{66}$. No quedó prácticamente ni un solo aspecto abierto a la duda o a la interpretación. Así, destaca en primer lugar una marcada jerarquización con el fin de que nada quedase al arbitrio de las distintas comunidades comuneras, con una clara preeminencia de la asamblea, que era la que marcaba las pautas políticas, intelectuales y de acción. Por otro lado se establecieron claramente los cometidos y responsabilidades de cada miembro y cargo, destacando la dureza ante la vulneración de las normas internas, pues el Código Penal de la Confederación declaraba que era delito toda vulneración voluntaria, es decir, dolosa, de

61 AGP, Papeles reservados de Fernando VII, t. 67, doc. 9, fols. 219 rto.-220 rto.

62 Gil Novales, Las sociedades patrióticas, 604-606.

63 Ruiz Jiménez, El liberalismo exaltado, 18-19.

64 Ruiz Jiménez, El liberalismo exaltado, 21.

65 Gil Novales, El Trienio liberal, 25-26.

66 AGP, Papeles reservados de Fernando VII, t. 67, doc. 17; Archivo Histórico Nacional (AHN), Estado, leg. 2.971. Un detallado análisis en Ruiz Jiménez, El liberalismo exaltado, 157-181. 
la ley de la comunidad de comuneros, y se incurría en falta si no era voluntaria (arts. 1 y 2$)^{67}$. También resulta interesante el empeño por imponer un estándar ético a sus componentes. Así, según los Estatutos, la confederación estaba facultada para advertir a los miembros por sus faltas en su conducta pública y privada, pudiendo dar los consejos oportunos para la reparación de sus acciones recriminables (art. 15). En esa línea se sitúa la prohibición de utilizar su influencia para conseguir empleos públicos (art. 17). Aparte de las obligaciones referidas a la observancia de los estatutos, el comunero estaba "estrechamente obligado á investigar las causas de los males que aflijan á su patria, ó impidan su felicidad”, debiendo proponer a la confederación lo que estimase conveniente para su remedio, promoviendo la prosperidad nacional (art. 16). Eran palabras que en realidad se referían a la obligatoriedad de hacer todo lo posible por denunciar y combatir el anticonstitucionalismo ${ }^{68}$.

La dirección de la Confederación recaía en la asamblea, siendo de carácter representativo (arts. 23 y 24), pues estaba formada por procuradores que representaban a cada merindad, es decir, a cada territorio provincial (art. 26). Sin duda este tipo de gobierno es muestra de la total asimilación comunera de la primacía de las Cortes instaurada en la Constitución de 1812, pues era la asamblea, trasunto de dichas Cortes, la que gobernaba y dirigía la Confederación, no estableciéndose un órgano ejecutivo sobre ella, ni tan siquiera a su altura, sino debajo y subordinado. Porque aunque la asamblea debía elegir a un comendador $^{69}$, al teniente comendador, al alcaide, al tesorero y a cuatro secretarios, todos los cuales conformaban una especie de junta directiva (art. 31), en modo alguno este órgano tenía capacidad de gobierno y dirección de la Confederación, ni cuidar la observancia de los estatutos, ni constituir merindades, ni reconocer a los comuneros como tales, ni comunicar acuerdos, ni recaudar fondos, atribuciones todas ellas que recaían sobre la asamblea, según su artículo 27. El comendador, por ejemplo, se encargaba solo de distribuir los negocios entre los secretarios, nombrar comisiones extraordinarias de trabajo, cuidar del orden y compostura de las discusiones asamblearias, y dirigía, abría y cerraba las sesiones, pudiendo hacer convocatorias extraordinarias. Es decir, todos eran cometidos meramente organizativos (art. 33). Un ejemplo está en que los secretarios se encargaban únicamente de redactar las actas y decretos que aprobase la asamblea, y estar atentos al cumplimiento de los acuerdos pendientes. Para facilitar el trabajo de la asamblea se debían constituir tres comisiones, una de justicia para conocer de las causas contra sus miembros, otra de vigilancia para cuidar de la seguridad de la Confederación, y otra administrativa encargada de fiscalizar las cuentas (arts. 37 a 39). La asamblea tenía su sede en Madrid como capital del reino (art. 28), y no podía constituirse sin estar presentes dos terceras partes de los procuradores (art. 29). Como se ha indicado, el lugar en el que se reunía, fuere donde fuere, era el alcázar de la libertad (art. 30) ${ }^{70}$.

Por debajo de la asamblea se encontraba la merindad, la cual coincidía básicamente con el territorio de una provincia (art. 6), asimilando por tanto la comunería el nuevo

\footnotetext{
67 Código Penal, 91.

68 Estatutos, 52.

69 El primer comendador fue el consejero de Estado Francisco López Ballesteros, en Ruiz Jiménez, El liberalismo exaltado, 20.

70 Estatutos, 54-58.
} 
y más racional mapa político español, el cual se terminó de pergeñar durante 1821 y se aprobó en enero de 1822. Así, la capital de provincia se erigía normalmente en sede de la merindad. Todos los comuneros de la merindad conformaban la comunidad, siendo por tanto la Confederación la unión de dichas comunidades (art. 5). Para formar una merindad era necesario que hubiese siete comuneros dispuestos a ello, debiendo ser autorizada por la asamblea (art. 43). Esos miembros de la merindad en realidad eran representantes de cada torre, unidad básica de reunión. Si la merindad alcanzaba los 17 componentes, debía nombrar una junta gubernativa de cinco comuneros (arts. 45 y 46). Esa junta gubernativa elegía a un castellano, el cual estatutariamente tampoco tenía atribuciones ejecutivas especiales a imitación del comendador, si bien es evidente que estaría dotado del carisma y liderazgo suficiente como para influir en el resto de comuneros de la merindad y dirigir las labores de proselitismo. Además se elegía un teniente castellano, un alcaide, un tesorero y dos secretarios (art. 49). La junta debía residir en la capital de la merindad, y el lugar en el

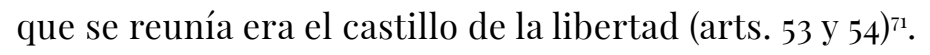

En cuanto a las torres, los miembros no podían ser menos de siete ni más de 50 (art. 8). No obstante, si se reunían establemente entre tres y seis comuneros en un lugar, podían conformar una casa fuerte dependiente de la torre más cercana (art. 10). Las torres tenían un alcaide que presidía las reuniones, un capitán de llaves, un depositario y un secretario (art. 65). Por su parte, las casas fuertes estaban compuestas por un capitán de llaves y un secretario $(\operatorname{art} .75)^{72}$.

Entrar a formar parte de la comunería se denominaba alistamiento y se requería gozar completamente de los derechos de español, tener más de 19 años de edad, "ser de buenas costumbres y gozar de reputacion de hombre honrado entre sus compatriotas", tener empleo, profesión o renta con la que subsistir, ser adicto al sistema constitucional "y aborrecer la tiranía bajo cualquier forma que se presente”, prestar el juramento, y sujetarse a las formas y pruebas señaladas en el Reglamento de la Confederación (art. 77). En principio el proceso de proposición de entrada y su definitiva aceptación requería unas formalidades e indagaciones exhaustivas (arts. 78 a 88), siendo no menos riguroso el acceso ${ }^{73}$.

La renovación de los cargos, hasta la de procurador, se realizaba cada 23 de abril, fecha emblemática para la Confederación (arts. 97 a 106). También estaba regulada la forma de llevar a cabo las sesiones, las discusiones, las proposiciones y las votaciones (arts. 107 a 120), así como la recaudación y administración de los fondos (arts. 121 a 133). Se regulaba una cuestión especialmente importante, la realización de las comunicaciones, detallándose quienes eran los responsables de hacerlas llegar, y las firmas y sellos que debían contar para verificar su veracidad (arts. 134 a 140). Finalmente se contemplaba la necesidad de gestionar un archivo por uno de los secretarios en la asamblea, en la junta gubernativa y en cada torre $(\text { arts. } 141 \text { y 142) })^{74}$.

\footnotetext{
Estatutos, 50 y $59-63$.

Estatutos, 50, 66 y 68.

Estatutos, 68-71.

Estatutos, 75-90.
} 


\section{La división}

La comunería, debido a su carácter secreto, la rápida difusión de sus postulados, su heterogeneidad, el gran número de sus componentes y la dificultad de mantener un permanente y uniforme estado de exaltación en todos sus miembros, no fue un grupo cohesionado, lo que provocó disensiones y una efímera trayectoria que terminó a la par que el Trienio Liberal. El estudio de las declaraciones de los comuneros riojanos realizadas en 1824 con el fin de ser depurados, permite señalar que prendió inicialmente entre los más exaltados, siendo liderada por estos. Sin embargo, al crecer rápidamente se fueron incorporando miembros menos ideologizados que moderaron a la sociedad, dando lugar a una amalgama de difícil gobierno. Los distintos testimonios revelan que la comunería estuvo conformada por una masa social muy variada de militares de rango inferior, clero local, escasos profesionales, labradores, artesanos y jornaleros. En el ámbito regional no aparece la elite, compuesta normalmente por cargos públicos, oficiales del ejército, hacendados, comerciantes, juristas y profesionales. Esta se ubicó con mayor comodidad en la masonería, próxima a la moderación. Por otro lado, también se ha podido observar la existencia de un odio extremo de los comuneros hacia los masones, posiblemente debido a que aquella sociedad nació de esta, a lo que habría que sumar la exaltación de los primeros. Sin embargo, se ha comprobado que hubo comuneros que expresamente manifestaron una defensa imperturbable de la religión y del rey, en realidad dos instituciones defendidas por el común de los liberales ${ }^{75}$.

En este sentido, no es posible acercar la comunería al primer republicanismo. Roca Vernet ya señaló que en el Trienio se dio en las filas exaltadas un discurso político republicano, si bien no se debe vincular a la comunería ${ }^{76}$. Simal Durán advirtió de la "pronunciada diversidad y fragmentación” del republicanismo en las primeras décadas del siglo XIX e indicó que algunos comuneros pudieron tener simpatías republicanas "o bien ser acusados de tenerlas para ser desacreditados", pero no se llegó a formar una línea de acción ${ }^{77}$. Finalmente, Gil Novales también había mostrado gran cautela al hablar de republicanismo y exaltación. Del líder comunero Romero Alpuente señaló que nunca se le podrá llamar republicano, pues para este diputado exaltado el rey era un servidor de la sociedad y una pieza más al servicio de la revolución. Concluyó señalando que "las fronteras entre exaltación liberal y republicanismo en España son, por lo menos, imprecisas, y esta imprecisión llega a ser un rasgo característico de la época”78.

Año y medio después del nacimiento de la Confederación de Comuneros se produjo una renovación, en concreto el 23 de octubre de 1822, que llevó a la radicalización de sus posturas ante la deriva moderada del régimen liberal y las constantes maquinaciones y acciones de los absolutistas ${ }^{79}$. Iris M. Zavala señaló que si el pueblo apoyó la revolución

75 Archivo Diocesano de Calahora (ADC), leg. 27/843/72.

76 Jordi Roca Vernet, “¿Hubo republicanos en el Trienio Liberal? Historia, moral y federalismo en el discurso republicano del primer liberalismo", Revista de Estudios Políticos 156 (2012): 85-123.

77 Juan Luis Simal Durán, "Exilio, liberalismo y republicanismo en el mundo atlántico hispano, 1814-1834" (Tesis de doctorado, Universidad Autónoma de Madrid, 2011), 60.

78 Alberto Gil Novales, "Exaltación liberal y republicanismo en España”, Revista de Historia Moderna 12 (1993): 255.

79 Ruiz Jiménez, El liberalismo exaltado, 22. 
de 1820 se debió entre otras cosas a que la Constitución les garantizaba que el anticuado sistema de impuestos sería abolido, pero que los comuneros luchaban no solo por eso, sino también por la libertad política, de pensamiento, de imprenta y de reunión ${ }^{80}$. En concreto, el desencadenante del nuevo posicionamiento de este liberalismo exaltado vino por el intento de golpe de Estado del mes de julio de 1822, finalmente abortado el día 7, el cual había sido auspiciado desde el absolutismo y que llevó en agosto al nombramiento como presidente del consejo de ministros al antiguo exaltado y compañero de Riego en el levantamiento del 1 de enero de 1820, Evaristo Fernández de San Miguel. Los disturbios del 7 de julio, en los que falleció el comunero y guardia real Mamerto Landáburu, provocarían también el nacimiento de una nueva sociedad patriótica en Madrid, la Sociedad Landaburiana, de notoria adscripción exaltada ${ }^{81}$, cuyo presidente sería Juan Romero Alpuente, el fundador de la comunería ${ }^{8_{2}}$.

El liberalismo exaltado fue testigo crítico de la actitud del rey ante el golpe de estado y de cómo solo gracias a las presiones de los liberales más comprometidos y ante la insistencia de la diputación permanente de las Cortes, fue capaz de nombrar un nuevo gobierno el 6 de agosto. No obstante, el nuevo ministerio no satisfizo a los exaltados debido a la deriva de San Miguel, al que ya se le tenía por miembro de la secreta y muy moderada Sociedad del Anillo. San Miguel había dado muestras de su pusilanimidad al haber ayudado a que los responsables del golpe de Estado no fuesen ejemplar y rápidamente castigados. En un principio fue el encargado de instruir la causa contra ellos, pero hizo lo posible por no actuar de forma ágil y contundente. Aunque la causa pasó tras su nombramiento ministerial al exaltado Juan de Paredes, su radicalismo e interés por llegar hasta el final trajo su apartamiento en el mes de octubre, pasando los autos a un tribunal especial ${ }^{83}$. Todas estas decisiones llevaron a la radicalización de una parte de los comuneros y por tanto a la mencionada renovación que se produjo a finales de ese mismo mes.

En la Confederación se reprodujo en realidad la misma división que existía entre los liberales españoles, la cual llevó a un segundo episodio en la breve trayectoria comunera, la determinante escisión de febrero de 1823, al separarse un amplio grupo más moderado. Romero Alpuente fue muy crítico con aquellos que, según él, propiciaron esta fragmentación definitiva de la comunería; opiniones y análisis ofrecidos por quien unos años después, al escribir su Historia de la revolución española, veía aquellos momentos con una perspectiva temporal suficientemente amplia ${ }^{84}$. Indicó que habían sido precisamente "los comuneros más honrados por la sociedad”, es decir, los más reconocidos por esta, los que al final la habían dividido y traicionado separándose de la Confederación. En concreto, se refería al antiguo guerrillero y médico Juan Palarea, al también médico Mateo Seoane y Sobral, y a los abogados Domingo María Ruiz de la Vega, Juan Oliver García y Ramón Salvato de Esteve. Nuestro autor señala que estos publicaron un manifiesto el 28 de febrero de 1823 animando a desertar y a pasarse al nuevo bando, viendo ahora como un error de la Confederación

\footnotetext{
$80 \quad$ Zavala, Masones, 79 .

81 Esta sociedad y el periódico El Zurriago impulsarían esta renovación y radicalización de los comuneros, ibídem.

82 Sophie Bustos, "El 7 de julio de 1822: la contrarrevolución en marcha", Revista Historia Autónoma 4 (2014): 129-143.

83 Bustos, "El 7 de julio de 1822", 140-143.

84 Escribió su Historia de la revolución española cerca de 1831 en el exilio, Alberto Gil Novales, "Estudio preliminar" I, LXVI.
} 
el haberles mantenido en ella y dispensado de asistir a las sesiones por su condición de diputados, cuando la incompatibilidad de estas dos condiciones debían haberla puesto de manifiesto ellos mismos ${ }^{85}$. Para él habían sido egoístas y traidores. Viene a culpar a este grupo, movido según él por el gobierno, de la división de la comunería cuando más unión se requería por la inestable situación del país. De igual manera criticó Romero Alpuente que estos mismos habían sido los que habían dado al traste de nuevo con las sociedades patrióticas, refiriéndose en particular a la Landaburiana, de la que Romero Alpuente era miembro activo, pues atribuía a Palarea el cierre de la misma ${ }^{86}$.

En la comunería se venían generando grandes tensiones internas entre los más exaltados y los que pretendían un acercamiento a la masonería. Esas diferencias se irían acrecentando, llevando finalmente a una vuelta de tuerca durante los días 22 y 23 de febrero de 1823 que provocó la definitiva división. Esta debilitó de tal manera a la sociedad secreta que la llevó a una irrelevante posición con la caída del régimen liberal. De esta escisión surgió la moderada Confederación de Comuneros Españoles Constitucionales, la cual se lamentaba precisamente de que la división de los liberales desde el mismo año 1820 había imposibilitado la revolución. Como se ha señalado, estos comuneros más moderados abogaban por la unión con la masonería, es decir una especie de vuelta a los orígenes. Los días previos se había visto en la Confederación un decálogo para la progresiva unión de masones y comuneros, si bien fue desechado ${ }^{87}$.

Ante esto, la noche del 22 de febrero de 1823 un grupo de 47 comuneros, entre los que había varios procuradores, es decir, representantes de las merindades, se reunieron en Madrid "para conferenciar sobre el estado en que se halla la Asamblea y Confederacion de Comuneros" en la que denominaron primera junta preparatoria ${ }^{88}$. La reunión estaba promovida por el grupo disidente y se erigió en asamblea constituyente de los autodenominados Comuneros Españoles Constitucionales. La convocatoria estaba motivada por la tensa situación existente en la Confederación. El texto que recoge las conclusiones de la asamblea se estructura en 14 observaciones y concluye con una propuesta de bases para la unión de los masones y los comuneros.

El documento es un compendio de agravios que se remontaban al 23 de octubre del año anterior, fecha de aquella primera renovación hacia la exaltación. Este grupo disidente venía observando y sufriendo desde entonces el acaloramiento de algunos procuradores, el cual entendían que había llevado a la destrucción de la fraternidad que, al parecer, hasta ese momento había reinado en la Confederación. Todo ello se fue acrecentando, llegándose al enfrentamiento. Por parte de los más exaltados se dirigieron anónimos desde Madrid contra algunos miembros disidentes, como por ejemplo los dirigentes de Granada. Los Comuneros Españoles Constitucionales recriminaban a la asamblea de la Confederación que no se hubiese adoptado ninguna medida para evitar lo anterior, ni que se corrigiesen los

85 Romero Alpuente, Historia de la revolución española, II, 316. El manifiesto se publicó en Marqués de Miraflores, Documentos, 228-238.

86 Alpuente, Historia de la revolución española, II, 317-318.

87 Ruiz Jiménez, El liberalismo exaltado, 25-26.

88 En AHN, Consejos, leg. 3635/54, fols. 11 vto.-27 rto., fuente utilizada por Ruiz Jiménez, El liberalismo exaltado, 22 y ss. También reproducido en Marqués de Miraflores, Documentos, 215-224, versión que utilizamos. 
excesos que al parecer había protagonizado la junta gubernativa de Valladolid, censurando además la arbitrariedad con la que había actuado en otras ocasiones ${ }^{89}$. También achacaba a dicha asamblea que se hubiese posicionado a favor del exaltado Juan Manuel de Paredes tras su apartamiento como fiscal en la causa contra los graves sucesos del 7 de julio de 1822, no defendiendo a algunos comuneros que habían preparado "un escrito mas fundado que el de Paredes"9o. Un nuevo ejemplo de la moderación del grupo secesionista.

Algunas observaciones señalaban que los acuerdos y resoluciones dados por la asamblea desde octubre habían sido nulos por no haberse cumplido varios artículos estatutarios relacionados con la convocatoria de reuniones, el quórum exigido y la aprobación de dichos acuerdos, así como el referido a la correspondencia, pues se había obviado a los procuradores para su envío. Parece claro que los comuneros más exaltados habían cometido ciertas irregularidades formales con el fin de entorpecer la acción obstruccionista y cada vez más importante de los comuneros más moderados. También recriminaban estos que se hubiese caído en el error de hacer recomendaciones para colocar a determinados comuneros y que se hubiese introducido en la comunería una comisión de carbonarios sin autorización. Otra de las observaciones que hacían se refería a la vulneración del secreto, pues el periódico $E l$ Zurriago había publicado cuestiones tratadas en sesiones extraordinarias de la asamblea y la asamblea se había convertido en "acérrima defensora" de sus ideas publicadas, perdiéndose la uniformidad en las ideas de todos los comuneros. Con todo ello la asamblea se había convertido en órgano de los caprichos o intereses de algunas personas. Finalmente, y en línea con su clara moderación, proponían unas bases para un tratado de unión con los masones, las cuales habían sido rechazadas por la asamblea comunera el 17 de febrero, a pesar de que en esa asamblea estaban procuradores que días después se integrarían con los disidentes ${ }^{91}$.

La segunda reunión preparatoria fue al día siguiente, el 23 de febrero, y una tercera el 24. En esta, la nueva asamblea de los disidentes Comuneros Españoles Constitucionales redactó una circular en la que se resumían los defectos de la asamblea de la Confederación, se informaba de la constitución de esta nueva asamblea y que en ella el día 24 se habían aprobado las bases que se adjuntaban y que iban a regir la nueva sociedad llamada Comuneros Españoles Constitucionales. En estas se proclama como principio básico la observancia "en toda su pureza de la Constitucion”, sin duda una manifestación de carácter moderado, se prohibía la pertenencia a esta de los miembros de otras sociedades secretas, con lo que se excluía a los miembros originarios de la Confederación, y se abogaba por dar los pasos necesarios para trabajar conjuntamente con los masones para defender la Constitución. La circular fue enviada el 28 de febrero. Dos días antes, el 26, en una última reunión de esta nueva asamblea se acordó que se remitiría a través de comuneros que ofreciesen confianza, facultándoles para que fuesen formando nuevas torres de entre cinco y 20 miembros con comuneros que quisiesen sumarse a la nueva sociedad, admitiéndose por ahora únicamente a los disidentes de la Confederación y no a nuevos miembros que no hubiesen pertenecido a ella, a no ser que fuesen "individuos muy recomendables por su notoria probidad y reputacion".

89 Marqués de Miraflores, Documentos, 215.

$90 \quad$ Marqués de Miraflores, Documentos, 216.

91 Marqués de Miraflores, Documentos, 217-223. 
Tampoco se podía admitir a quien no fuese propietario o no tuviese empleo para sostenerse y quien no estuviese libre de "mancha alguna en sus costumbres públicas o privadas". Todo se debía verificar con el consiguiente juramento de reconocimiento como única, legítima y constituyente, de la nueva asamblea instalada el 23 de febrero. Con la circular se acompañó un largo manifiesto en el que la nueva asamblea explicaba las razones de la escisión, repitiendo los argumentos mostrados en las observaciones que ya había hecho llegar a la Confederación, pero utilizando la retórica propia de un texto de estas características ${ }^{92}$.

Pocos días después, ya en el mes de marzo, la asamblea de la Confederación de Comuneros respondió a la disidencia e hizo llegar a todos sus confederados un manifiesto que respondía y rebatía las observaciones redactadas por los disidentes en la primera de sus juntas preparatorias ${ }^{93}$. En él señalaba que estos se habían reunido de manera clandestina y, en contra de los juramentos y estatutos de la Confederación, habían publicado calumnias y maledicencias en un ataque directo contra ella promoviendo la división. El mayor lamento hacía referencia a la fuerza que esto iba a dar "a los enemigos de la Constitucion", y dejaba claro que, a pesar de las calumnias, la asamblea se mantendría dentro de los límites de la buena educación y la dignidad. Así, con respecto a aquella inicial observación de los Comuneros Constitucionales negó las discordias argüidas e indicó que la vehemencia se debía a que los procuradores “disidentes” justificaban las decisiones moderadas del Gobierno ${ }^{94}$.

Sobre los anónimos dirigidos no solo al procurador de Granada, sino también al de Málaga, ambos de ese grupo disidente, la asamblea señalaba que se trataba precisamente de eso, de anónimos, que no debían ser considerados como documentos suficientes como para actuar. El asunto de los excesos de la exaltada junta de Valladolid incluyó al entonces procurador de Logroño entre los disconformes ya antes del 23 de octubre de 1822, siendo además receptor de una carta injuriosa que le llevó a posicionarse contra los de Valladolid junto con los procuradores de Málaga y Granada. Finalmente los procuradores disidentes fueron menos que los fieles. En concreto los primeros eran diez y los segundos 32, estando vacantes seis. Los primeros fueron, además de los de Logroño, Málaga y Granada, los de Murcia, Jaén, Barcelona, León Tarragona, Guadalajara y Castellón"5.

\section{Represión contra la comunería tras el Trienio Liberal}

Poco después de la entrada en Madrid de las tropas francesas del duque de Angulema, realizada el 24 de mayo de 1823, Fernando VII comenzó una intensa labor de depuración y represión de los constitucionales y especialmente de los miembros de las sociedades secretas, focos fundamentales de lucha liberal. Para ello se fueron tomando una serie de medidas contra sus miembros, desarrollándose durante los dos años siguientes una gran represión ${ }^{96}$. No obstante, el inicial ímpetu represor se vio mitigado debido a que los elementos más peligrosos habían abandonado el país. Esto llevó a adoptar medidas

\footnotetext{
92 Marqués de Miraflores, Documentos, 225-238.

93 Marqués de Miraflores, Documentos, 191-214.

94 Marqués de Miraflores, Documentos, 192.

95 Marqués de Miraflores, Documentos, 193, 194 y 214.

96 Juan José Morales Ruiz, “La represión de la masonería durante el reinado de Fernando VII”, en La Iglesia española en la crisis del Antiguo Régimen, coord. Isidro Sepúlveda Muñoz y Blanca Buldain Jaca (Madrid: UNED, 2003), 207.
} 
de control ofreciéndose la posibilidad de renegar de su militancia liberal mediante unas confesiones absolutorias a realizar no ante las autoridades civiles o judiciales, sino ante la Iglesia, las denominadas espontaneaciones.

En 1823 el real decreto del 1 de octubre restablecía la legalidad previa al 7 de marzo de 1820. El 11 de diciembre el fiscal del reino elaboró un informe sobre prohibición de la masonería ${ }^{97}$. Pero fue al año siguiente cuando se aprobaron las normas fundamentales para perseguir a los miembros de las sociedades secretas. Mediante el decreto del 23 de junio de 1824 se condenó a pena de muerte a los miembros de las sociedades secretas, aunque por real cédula del 1 de agosto del mismo año se indultó a todos los que en un mes se presentaran ante las autoridades e informasen sobre la logia o sociedad a la que hubiesen pertenecido, entregando además los enseres que en relación a ellas tuviesen, tales como insignias, estandartes, estatutos y otros documentos ${ }^{98}$. Con anterioridad otra real cédula del 1 de mayo de 1824 había indultado a toda persona que desde enero de 1820 y hasta el 1 de octubre de 1823 , es decir durante el Trienio Liberal, hubiera participado en pro del sistema constitucional a excepción de los que, después de la abolición de la Constitución, continuasen reuniéndose en sociedades secretas. Todo parece indicar que poco a poco Fernando VII fue reduciendo la presión y persecución contra los miembros de estas sociedades, pero no renunció al uso de otro tipo de acciones menos agresivas con el fin de descabezarlas y anularlas. Su engañosa benevolencia con los miembros de aquellas sociedades estaría acompañada por otras iniciativas menos llamativas y aparentemente indulgentes, pero efectivas y con finalidad indagatoria. Así, urdió un procedimiento para facilitar la renuncia expresa de los antiguos miembros de las sociedades secretas mediante la contestación a una serie de preguntas acerca de su pertenencia a aquellas. Las preguntas fueron lo suficientemente exhaustivas como para abarcar todos los ámbitos de su actividad, por lo que sus respuestas proporcionaron una información esencial destinada sin duda a controlar y reprimir los focos liberales y evitar su renacimiento. A ello ayudó que en casi todos los casos los declarantes tenían un gran interés por desvincularse de su pasado liberal y borrar su pertenencia, lo que llevó a que los espontaneados se explayasen y aportasen un buen número de detalles, y sobre todo nombres.

El rey otorgó a la Iglesia especial protagonismo en este procedimiento de renuncia, control e indagación de los antiguos miembros de las sociedades secretas, actuando como agente al servicio del antiliberalismo. Se valió de su fuerza moral en la sociedad y su aparente desvinculación del gobierno para lograr una información detallada a través de dichas espontaneaciones. A los ordinarios diocesanos se les encomendó esta labor mediante la real orden del 25 de septiembre de 1824 y una circular del 8 de octubre del mismo año sobre cómo proceder contra los eclesiásticos que hubiesen pertenecido a las sociedades

97 Morales Ruiz, “La represión de la masonería”, 210.

98 El artículo $2^{\circ}$ de esta norma decía: "Todos los que hayan pertenecido á dichas sociedades secretas de cualquier clase y denominacion que fueren, gozarán del indulto concedido por mi decreto de $1 .^{\circ}$ de mayo de este año, con las excepciones que comprende, poniéndose por lo mismo en libertad á los que se hallasen presos ó detenidos en las cárceles, y suspendiéndose la continuacion de las causas, siempre que se presenten espontáneamente á solicitar dicho indulto ante las autoridades competentes, señalando la logia ó sociedad á que hayan pertenecido y entregando sus diplomas y las insignias y papeles que tuvieren relativos á la asociacion, dentro de un mes contado desde la publicacion de este mi Real Decreto". 
secretas. Así, aquellos que se quisiesen acoger al indulto decretado el 1 de agosto debían hacerlo compareciendo ante los eclesiásticos que señalasen los obispos y arzobispos de cada diócesis. Se garantizaría el mayor de los sigilos y se entregaría a los interesados un resguardo de su declaración. En principio era una oportunidad para reincorporarse a la sociedad y librarse de represalias y persecuciones; sin embargo, para la Corona se trataba de una oportunidad única para extraer una información muy valiosa. Con el fin de presionar aún más a los antiguos miembros de las sociedades secretas y evitar así la continuidad de ellas, unos días después, el 9 de octubre, se dictó una real orden que declaraba que quedaban sujetos a la pena de muerte y a la confiscación de sus bienes como reos de lesa majestad divina y humana, los masones, los comuneros y otros miembros de sociedades secretas que no se acogiesen al indulto ${ }^{99}$.

Durante los años posteriores a la definitiva salida de los franceses de 1814 y hasta el Trienio Liberal, la Iglesia española había luchado por la prohibición y persecución de la masonería $^{100}$. El 15 de agosto de 1814 se publicó un edicto firmado por Hércules Consalvi, secretario de Estado del Vaticano, en el que se prohibía la masonería en los Estados Pontificios. Este edicto llegaría a España y Fernando VII, que lo vio con agrado, se lo hizo llegar a la Inquisición. El inquisidor general Francisco Javier Mier y Campillo, tras hacer público el 2 de enero de 1815 aquel edicto, publicaba unos meses después, el 5 de abril, un decreto en el que señalaba que tras las desgracias producidas por los franceses, había que atajar otro mal en España, la pérdida de la fe, viendo con horror "los rápidos progresos de la incredulidad y la espantosa corrupción de las costumbres que ha contaminado el suelo español” ${ }^{101}$. Ofrecía un período de gracia hasta finales de año para que los herejes abjurasen y los culpables confesasen sus graves pecados en secreto, si bien los confesores que debían absolver tenían que mandar a la Inquisición el documento en el que quedase fijada dicha abjuración y renuncia, rompiendo por tanto el secreto de toda confesión en un claro ejemplo del control de los díscolos. A pesar de todo ello la masonería no desapareció y siguió permaneciendo en la clandestinidad hasta 1820.

Una vez cerrado el período constitucional de 1820-1823, la Iglesia española retomó su cruzada contra las sociedades secretas. El 13 de septiembre de 1821 Pío VII había publicado el Breve Ecclesiam Christi contra el carbonarismo y por extensión contra toda sociedad secreta. El 24 de abril de ese año el nuncio Giacomo Giustiniani había comunicado a Consalvi la aparición de la sociedad de comuneros compuesta por los revolucionarios más exaltados y que, según el nuncio, inspiraba terror en los propios liberales. También informaría de que se había establecido en Madrid una logia de carbonarios. Ya en octubre de 1822 el nuncio daba noticia a Consalvi de la pertenencia del diputado Romero Alpuente a la comunería ${ }^{102}$.

Sin embargo, el Breve papal del 13 de septiembre de 1821 no fue publicado por el

\footnotetext{
99 Javier Alvarado Planas, Masones en la nobleza de España (Madrid: La Esfera de los Libros, 2016), 171-175.

100 Pedro Olea Álvarez, "Iglesia y masonería. El Archivo de la Nunciatura de Madrid. 1800-1850", en Masonería, política y sociedad, ed. José Antonio Ferrer Benimeli (Zaragoza: Centro de Estudios Históricos de la Masonería Española, 1989), vol. 2, 571-586.

101 Olea Álvarez, "Iglesia y masonería", 572.

102 Olea Álvarez, "Iglesia y masonería", 573.
} 
episcopado español en aquellas fechas. Las razones parecen evidentes. El momento político no era el más propicio, pues ese tipo de sociedades, aunque secretas, no estaban prohibidas entonces en España y la mayoría de los obispos asumió, aunque no compartió, el orden constitucional. No sería hasta la caída del régimen liberal cuando los obispos comenzaron a hacerse eco de aquel documento papal haciéndolo suyo y publicándolo junto con sus propias cartas pastorales. Su posicionamiento se comenzó a hacer público de manera temprana. El primero de ellos fue el obispo de Orihuela, Simón López García, que remitió el 20 de diciembre de 1823 a la nunciatura el documento publicado informando el día 1 de marzo de 1824 de los buenos resultados de su edicto. El siguiente sería el obispo de Jaén, Andrés Esteban Gómez, en ese mismo mes de marzo. El nuncio envió también ese mes el documento y la pastoral del obispo jienense al resto de obispos, de lo que informaría el 21 de marzo a la Santa Sede. En los sucesivos meses serían varios los que seguirían el mismo camino, publicando cartas pastorales y documentos haciéndose eco de la condena papal de 1821, como por ejemplo los de Segovia, Ceuta, Zaragoza, Orense, Astorga, Tuy, Santander, Málaga, Pamplona y Lugo ${ }^{103}$.

Aunque en un principio parece que hubo dudas acerca de si el breve papal afectaba a los comuneros, el secretario de Estado Giulio Maria Della Somaglia, tras el estudio de su reglamento, los incluiría de manera expresa. El nuevo papa León XII había publicado en mayo su primera encíclica Ubi primum, en la que también condenaría las sociedades secretas. En carta del 12 de julio de 1824 Giustiniani informaba además al secretario de Estado Vaticano que S. M. iba a publicar de forma inminente una ley contra todas ellas ${ }^{104}$. Ya se ha visto arriba que entre mayo y septiembre la Corona aprobó varias normas por las que se perseguía a masones y comuneros, pero también otras en las que se les indultaba bajo determinadas condiciones y estableciendo estrictos procedimientos. Aunque la Corona tenía motivos propios para cercenar la actividad de las sociedades secretas por ser focos liberales, da la sensación de que actuó a remolque de aquellas incendiarias y extremas cartas episcopales del mes de marzo y debido al aumento de la presión que ejerció la jerarquía eclesiástica española.

Son escasas aún las informaciones sobre la actividad desarrollada en las distintas diócesis. Una de las que más rápida y efectivamente llevó a cabo las señaladas espontaneaciones fue la de Calahorra y La Calzada. La señalada real orden del 25 de septiembre de 1824 por la que se había aprobado su realización fue notificada al obispado el 22 de octubre y su obispo, Atanasio Puyal y Poveda, se dispuso a ponerla en práctica de forma casi inmediata. A alguien debía encomendar la organización de las mismas y el designado fue Cornelio Ibarrondo, vicario general de la diócesis desde el año anterior y canónigo de la catedral de Santo Domingo de la Calzada, donde residía. El 14 de noviembre de 1824 le remitió una carta mediante la que le informó que había determinado designarle "para cumplir con lo que prescribe la Real orden de 25 de septiembre de este año, en la qual se ha servido S. M. resolver que los que hayan pertenecido á congregaciones de francmasones,

103 Olea Álvarez, "Iglesia y masonería”, 574-576.

104 Olea Álvarez, "Iglesia y masonería”, 577-578. El 13 de marzo de 1825 se publicaría la constitución apostólica "Quo graviora" contra las sociedades secretas. 
comuneros y otras sociedades secretas de las prohibidas por las Leyes, qualquiera que sea su denominación, quieran espontanearse para gozar del indulto”. Su trabajo consistiría en tomar declaración a aquellos que de manera voluntaria quisiesen renunciar a su militancia en sociedades secretas. Puyal señalaba en la carta que el rey había decretado que esas declaraciones debían hacerse exclusivamente ante los arzobispos, obispos o los eclesiásticos que estos designasen según la fórmula adjunta aprobada por el rey y que le había sido notificada el 18 de octubre a la junta reservada de Estado, cuyo presidente la había hecho llegar a los prelados el día 22 de octubre. Las espontaneaciones debían estar firmadas por los deponentes y por el vicario delegado absolviéndoles de las censuras o penas eclesiásticas en las que hubieran podido incurrir y extendiéndose la correspondiente diligencia. Todo se debía hacer de manera sigilosa y discreta y tenían la obligación de entregar al declarante una certificación que acreditase la espontaneación. El resultado de los interrogatorios debía remitirse a la señalada junta reservada de Estado. También indicaba Puyal que esta posibilidad de espontanearse debía ponerse en conocimiento de todos los párrocos, para que estos a su vez informasen desde el púlpito a la feligresía y con ello animasen al arrepentimiento ${ }^{105}$.

Como se ha señalado, en la diócesis de Calahorra y La Calzada fue Cornelio Ibarrondo el encargado de organizar "las declaraciones espontaneas de los Masones, Comuneros y qualesquiera individuos de sectas y reuniones secretas prohibidas" que deseaban el indulto, si bien en algunos casos para la toma de declaración delegó en otros eclesiásticos ${ }^{106}$. Ibarrondo fue uno de aquellos miembros del clero diocesano que contaron con la plena confianza del obispo Puyal, siendo por tanto coincidentes las posiciones políticas de ambos. Su ideología política y su visión de la Iglesia eran claramente conservadoras. Además de ser su vicario diocesano fue comisionado por el obispo en varios asuntos de gran complejidad con el fin de realizar labores de indagación e instrucción. No solo contribuiría a ello su fidelidad, sino también su condición de abogado, pues se formó en derecho, llegando al grado de doctor. Fue también consultor de la Inquisición de Navarra, es decir, jurista que asesoraba a dicho tribunal. En el año 1803 había optado a la cátedra de Filosofía de la Universidad de Oñate, puesto que no logró ${ }^{107}$.

En la diócesis depusieron 24 antiguos comuneros. Las primeras espontaneaciones comenzaron el día 23 de noviembre de 1824 y se cerraron el 7 de enero de 1825, realizándose en total ocho, especialmente de las torres comuneras de Logroño. Las segundas declaraciones se ciñeron a 12 miembros de la torre comunera de Navarrete y se realizaron entre el 28 de enero y 12 de febrero de 1825. Las últimas fueron cuatro espontaneaciones puntuales y muy distanciadas en el tiempo, pues la primera se realizó el 7 de marzo, la segunda el 13 octubre y finalmente las dos últimas los días 10 y 11 de mayo de 1826. Las espontaneaciones se estructuraron a través de cinco preguntas. En la primera se les preguntó su nombre, de dónde eran naturales, en qué lugar residían, qué edad tenían, su estado civil y su ocupación, preguntándoles también si habían sido sobornados para efectuar la espontaneación. La

105 Archivo Catedral de Santo Domingo de la Calzada (ACSDC), leg. 146/02.

106 ADC, leg. 27/843/72.

107 María Rosa Ayerbe Iríbar, “Universidad de Sancti Spiritus de Oñate. Fuentes y líneas de investigación”, Aquilafuente 122 (2008): 135. 
segunda pregunta se refería a qué personas les habían propuesto o impulsado a formar parte de la asociación secreta y quiénes la integraban. La tercera pregunta aludía a si conservaban insignias, estatutos, reglas, certificaciones, diplomas u otros documentos. La cuarta preguntó por los asuntos que se trataban en las reuniones, los objetos religiosos y políticos que se usaban, y si se pagaba contribución económica. La quinta y última se refería a si quedaban logias o reuniones activas en el momento de la espontaneación, en dónde y quiénes eran sus miembros ${ }^{108}$.

\section{Conclusión}

La comunería surgió a principios de 1821 desde dentro de la masonería, debido principalmente a la moderación de los miembros de esta. Algunos liberales exaltados, liderados por Juan Romero Alpuente, entendieron que era necesario aumentar el compromiso liberal y luchar por el desarrollo pleno del sistema constitucional ante los embates absolutistas que aquel ya estaba sufriendo, y también por el freno a las reformas que se observaba no solo en el gobierno, sino en las Cortes.

Su regulación fue exhaustiva y extremadamente jerárquica, lo que facilitó que muy pronto se extendiese por prácticamente todas las provincias españolas. A ello se sumó una mayor laxitud que la masonería, llegándose a establecer en los ámbitos rurales y en las distintas capas sociales. Los comuneros, debido a su inicial exaltación, especialmente de sus dirigentes, y a su procedencia masónica, manifestaron un odio extremo hacia los masones; sin embargo, no renunciaron ni al rey ni a la religión, por lo que no es posible considerar a la comunería como un preámbulo del republicanismo.

La división interna se produjo por el deseo de algunos elementos moderados de volver a acercarse a la masonería, si bien una buena parte quería permanecer en la exaltación. Esto llevó a la escisión, naciendo a principios de 1823 la Confederación de Comuneros Constitucionales. Todo ello, sumado al derrumbe del sistema constitucional, provocó al final su supresión y desaparición, no teniendo continuidad tras el retorno al liberalismo con la muerte de Fernando VII diez años después.

\section{Fuentes}

Archivo Catedral de Santo Domingo de la Calzada. Legajo 146/02

Archivo Diocesano de Calahora. Legajo 27/843/72

Archivo General de Palacio. Papeles reservados de Fernando VII, t. 67, documentos 9 y 17

Archivo Histórico Nacional. Consejos. Legajo 3635/54

Archivo Histórico Nacional. Estado. Legajo 2971

Diario de Sesiones de Cortes. 1821

El Constitucional. 30 de agosto de 1820

Semanario patriótico. 21 de noviembre de 1811

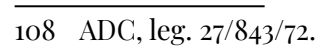




\section{Bibliografía}

Alcalá Galiano, Antonio. Recuerdos de un anciano. Madrid: Imprenta Central, 1878.

Alvarado Planas, Javier. Masones en la nobleza de España. Madrid: La Esfera de los Libros, 2016.

Álvarez Junco, José. Mater dolorosa. La idea de España en el siglo XIX. Madrid: Taurus, 2001.

Arnabat, Ramón. La revolució de 1820 i el Trienni Liberal a Catalunya. Vic: Eumo editorial, 2001.

Berzal de la Rosa, Enrique. Los comuneros. De la realidad al mito. Madrid: Sílex, 2008.

Berzal de la Rosa, Enrique. "El mito de los comuneros de Castilla en la construcción del Estado-Nación español”. Alcores 12 (2011): 55-73.

Biblioteca de la Religion, ó sea, Coleccion de obras contra la incredulidad y errores de estos últimos tiempos, 25 vols. Madrid: Imprenta de D. E. Aguado, 1826-29.

Bustos, Sophie. "El 7 de julio de 1822: la contrarrevolución en marcha". Revista Historia Autónoma 4 (2014): 129-143.

Bustos, Sophie. "La nación no es patrimonio de nadie. El liberalismo exaltado en el Madrid del Trienio Liberal (1820-1823): Cortes, gobierno y opinión pública”. Tesis de Doctorado en Historia, Universidad Autónoma de Madrid, 2017.

Canga Argüelles, José. Reflexiones sociales, ó idea para la Constitucion española, que un patriota ofrece a los representantes de Cortes. Valencia: Imprenta de José Estevan, 1811.

Constitución de la confederacion de los caballeros comuneros, y reglamento para el gobierno interior de las fortalezas, torres y castillos de todas las merindades de España. Con algunas notas, que aunque no se pusieran, no por eso dejaria de irlas haciendo á sus solas el lector. Madrid: Imprenta del Imparcial, 1822.

De la Fuente, Vicente. Historia de las sociedades secretas antiguas y modernas en España, especialmente de la Francmasonería. Lugo: Imprenta de Soto Freire, 1870 y 1881.

Estatutos de la Confederación de Comuneros Españoles. Precede un resúmen de la historia de las Comunidades de Castilla. Valencia: Imprenta de José Ferrer de Orga, 1822.

Extracto del expediente militar instructivo formado para la exhumacion de los huesos de los héroes castellanos Padilla, Bravo y Maldonado, y copias de la órden, acta celebrada y decreto de aprobación. Madrid: Imprenta de D. Mateo Repullés, 1821.

Gil Novales, Alberto. Las Sociedades patrióticas (1820-1823). Las libertades de expresión y de reunión en el origen de los partidos políticos. Madrid: Tecnos, 1975.

REHMLAC+, ISSN 1659-4223, vol. 12, no. 2, diciembre 2019 / junio 2020 
Gil Novales, Alberto. El Trienio liberal. Madrid: Siglo XXI, 1980.

Gil Novales, Alberto. "Estudio preliminar". En Juan Romero Alpuente, Historia de la revolución española y otros escritos. Madrid: Centro de Estudios Constitucionales, 1989.

Gil Novales, Alberto. "Exaltación liberal y republicanismo en España". Revista de Historia Moderna 12 (1993): 249-258.

Gil Novales, Alberto. “Gallardo y Blanco, Bartolomé José”. En Diccionario biográfico de España (1808-0833). De los orígenes del liberalismo a la reacción absolutista. Madrid: Fundación Mapfre, 2010.

López Caneda, Ramón. "La sociedad secreta de Caballeros Comuneros de Astorga". Astórica 4 (1986): 55-104.

López Caneda, Ramón. “Astorga 1824. Depuración política y ficha policial sobre caballeros comuneros, liberales exaltados, masones y demás afectos a la ideología liberal”. Astórica 8 (1989): $185-198$.

Maravall, José Antonio. Las comunidades de castilla. Una primera revolución moderna. Madrid: Revista de Occidente, 1963.

Marqués de Miraflores. Apuntes histórico-críticos para escribir la historia de la revolucion de España, desde el año 1820 hasta 1823. Londres: Oficina de Ricardo Taylor, 1834.

Martínez de la Rosa, Francisco. La viuda de Padilla. Madrid: Imprenta que fue de García, 1814.

Miñano, Sebastián. Examen crítico de las revoluciones de España. De 1820 a 1823 y 1836. París: Imprenta de Crapelet, 1837.

Mondejar, Manuel. "Alliances et conflits au sein des sociétés secrètes libérales: la confédération des chevaliers comuneros ou les limites de l'illusion démocratique durant le triennat constitutionnel 1820-1823". Tesis de Doctorado en Historia, Universidad de AixMarseille I, 2007.

Morales Ruiz, Juan José. "La represión de la masonería durante el reinado de Fernando VII”. En La Iglesia española en la crisis del Antiguo Régimen. Coordinado por Isidro Sepúlveda Muñoz y Blanca Buldain Jaca. Madrid: UNED, 2003.

Olea Álvarez, Pedro. "Iglesia y masonería. El Archivo de la Nunciatura de Madrid. 180o1850". En Masonería, política y sociedad. Editado por José Antonio Ferrer Benimeli. Centro de Estudios Históricos de la Masonería Española, 1989.

Ortiz García, Antonio. “Masones y comuneros en la Diócesis de Sigüenza tras el Trienio liberal (1823)”. Wad-al-Hayara, Revista de estudios de Guadalajara 13 (1986): 263-275.

REHMLAC+, ISSN 1659-4223, vol. 12, no. 2, diciembre 2019 / junio 2020 
Pérez Joseph. Los comuneros. Madrid: Historia 16, 1997.

Quintana, Manuel José. Poesías patrióticas. Madrid: Imprenta Real, 1808.

Robertson, William. The History of the Reign of the Emperor Charles V. Dublin: Smith, 1769.

Roca Vernet, Jordi. “¿Hubo republicanos en el Trienio Liberal? Historia, moral y federalismo en el discurso republicano del primer liberalismo". Revista de Estudios Políticos, 156 (2012): 85-123.

Ruiz Jiménez, Marta. El liberalismo exaltado. La confederación de comuneros españoles durante el Trienio Liberal. Madrid: Ed. Fundamentos, 2007.

Sánchez Martín, Víctor. "Rafael del Riego. Símbolo de la revolución liberal”. Tesis de Doctorado en Historia, Universidad de Alicante, 2016.

Sandoval, Prudencio. Historia de la vida y hechos del emperador Carlos V. Zaragoza: 1634.

Segarra, Josep Ramón. "La turbación de los tiempos: ruptura temporal e historia en la construcción de las culturas políticas”. En La creación de las culturas políticas modernas. 1808-1833. Coordinado por Miguel Ángel Cabrera y Juan Pro. Madrid: Marcial Pons, Prensas de la Universidad de Zaragoza, 2014.

Simal Durán, Juan Luis. "Exilio, liberalismo y republicanismo en el mundo atlántico hispano, 1814-1834”. Tesis de doctorado en Historia, Universidad Autónoma de Madrid, 2011.

Torrecilla, Jesús. España al revés. Los mitos del pensamiento progresista (179o-1840). Madrid: Marcial Pons, 2016.

Zavala, Iris María. Masones, comuneros y carbonarios. Madrid: Siglo XXI, 1971. 